\title{
A Systematic Literature Review to Determine the Web Accessibility Issues in Saudi Arabian University and Government Websites for Disable People
}

\author{
Muhammad Akram \\ College of Graduate Studies \\ Universiti Tenaga Nasional \\ Jalan IKRAM-UNITEN, 43000 Kajang, Selangor, \\ Malaysia
}

\author{
Rosnafisah Bt Sulaiman \\ College of Information Technology \\ Universiti Tenaga Nasional \\ Jalan IKRAM-UNITEN, 43000 Kajang, Selangor, \\ Malaysia
}

\begin{abstract}
Kingdom of Saudi Arabia has shown great commitment and support in past 10 years towards the higher education and transformation of manual governmental services to online through web. As a result number of university and egovernment websites increased but without following the proper accessibility guidelines. Due to this many disable peoples may not be fully benefited the contents available on university and government websites. According to the World Health Organization (WHO) report, there are more than one billion people all over the world facing different kind of disabilities. Almost 720,000 Saudi nationals are disable which is about $4 \%$ of total Saudi population. The objective of this study is to review the existing literature to identify the web accessibility issues in Saudi Arabian university and government websites through a systematic literature review. Several scholarly databases were searched for the research studies published on web accessibility evaluation globally and in Saudi Arabia from 2009 to 2017. Only 15 (6 based on Saudi Arabia and 9 global) research articles out of 123 articles fulfilled the selection criteria. Literature review reveals that web accessibility is a global issue and many countries around the world including Saudi Arabia are facing web accessibility challenges. Moreover web accessibility guidelines WCAG 1.0 and WCAG 2.0 are not addressing many problems which are faced by user and some guidelines were not effective to avoid the user problems. However, findings in this study open a new dimension in web accessibility to do extensive research to determine the web accessibility criterions/standards in context of Saudi Arabia.
\end{abstract}

Keywords-Web accessibility; disability; e-government; web contents accessibility guidelines; WCAG 1.0; WCAG 2.0; accessibility evaluation

\section{INTRODUCTION}

Websites play a vital role to get the information in different fields of life such as, education, employment, government, commerce, health care etc. These websites should be accessible for all users including disable people so that they can utilize all provided services. According to the report published on disability by the WHO, there are more than one billion people worldwide live with different kinds of disabilities [1]. These disable persons are considered as people who have long term or permanent physical, cognitive, mental, intellectual, psychological or sensory impairments which constitute a barrier or obstacle for them to fully, equally, and effectively participate in all society activities as other people [2]. Like other countries, Saudi Arabia also have reasonable number of disable person. According to the news published on Saudi national newspaper, there are almost 720,000 Saudi nationals are disable. It is around 4\% of total Saudi population [3].

In 2006 [2], UN assembly passed a treaty for disable people's rights which aims to promote and protect their rights. It covers a number of key areas such as employment, education, health and accessibility. The elementary issue of article 9 of the convention entails countries to determine and eradicate obstacles and barriers that hinder disabled people from accessing their environment, transportation, public facilities, services and information technologies (ICT). The United Nations have recently extended these efforts to include web accessibility in Article 9, Section-2, paragraph-h. According to United Nation treaty collection [4], about 187 countries already signed the treaty and Saudi Arabia signed this treaty in June 2008 and makes the legislation which addresses the disability issues. This law was mainly addressing the employment and skills development which did not clearly contain the rules for web accessibility.

Study which was conducted by the UK office for disability studies noted that the main reason of using Internet by disable people was to use the services provided by the government web sites [5].

It is very important to design and implement governmental and university websites by following the web accessibility guidelines. It will ensure that disable people can also benefit from services provided by governmental website. Therefore, in this paper we have reviewed the existing research studies conducted in Saudi Arabia and globally to identify the web accessibility issues in both university and governmental websites. Accessibility issues are highlighted and proposed the further need of in-depth research to design the web accessibility guide lines in context of Saudi Arabia. The rest of research paper is organized into seven sections: Section 2 briefly explains the web accessibility and principles of web content accessibility guidelines 2.0. Section 3 describes about the legislation on web accessibility. Section 4 discuss about the e-services provided by the Saudi government and universities. Section 5 discuss about existing research studies conducted on web accessibility. Section 6 talk about the research 
methodology which is adopted to complete this study. Section 7 presents the discussion and recommendation. Section 8 gives the conclusion and future work.

\section{WEB ACCESSIBLITY AND PRINCIPLES OF WEB CONTENT ACCESSIBILITY GUIDELINE 2.0 (WCAG 2.0)}

According to the Information Resources Management Association (IRMA) web accessibility is "making web content available to all individuals, regardless of any disabilities or environmental constraints they experience" [6].

World Wide Web Consortium establishes the Web Accessibility Initiative (WAI) in 1997 to design web accessibility guidelines. In 1999, they finalized and recommended to use Web Content Accessibility Guidelines (WCAG 1.0) to design websites [7]. At the end of 2008, WCAG-2.0 was published that applies broadly to more advance technologies [8]. WCAG 2.0 contains 12 guide lines which are based on four main principles; 1) perceivable 2) operable 3) understandable and 4) robust. These guidelines are shown in Table 1 below:

TABLE. I. PRINCIPLES OF WEB CONTENT ACCESSIBILITY GUIDELINE 2.0

\begin{tabular}{|l|l|}
\hline Principles & Guidelines \\
\hline Principle 1: Perceivable & $\begin{array}{l}\text { - Website should provide the alternative text } \\
\text { for all non-text contents. }\end{array}$ \\
& $\begin{array}{l}\text { If there is any multimedia file in web site } \\
\text { then web designer must include the caption } \\
\text { for those files. }\end{array}$ \\
& $\begin{array}{l}\text { Website contents should be presented in such } \\
\text { a way that if someone use assistive } \\
\text { tochnology then meaning of contents not }\end{array}$ \\
\hline lose. \\
\hline Principle 2: Operable \\
website should be very easy to read and hear.
\end{tabular}

The goal of these guidelines is to promote and achieve web accessibility for people suffering with different kind of disabilities.
WCAG 2.0 encompasses a series of checkpoints under 12 guidelines. W3C working group assigned priority levels to each checkpoint on bases of its impact on accessibility. Total three priority level was defined and for each there are numbers of checkpoints those need to be satisfied to achieve corresponding conformance level [8] which are listed in the following Table 2:

TABLE. II. CONFORMANCE LEVEL AND CHECKPOINTS

\begin{tabular}{|l|l|}
\hline Conformance level & Total number of checkpoints \\
\hline $\begin{array}{l}\text { "Single-A": Satisfied all checkpoints of } \\
\text { Priority1. }\end{array}$ & 25 \\
\hline $\begin{array}{l}\text { "Double-A": Satisfied all checkpoints } \\
\text { of Priority } 1 \text { and } 2 .\end{array}$ & $25+13=38$ \\
\hline $\begin{array}{l}\text { "Triple-A": Satisfied all checkpoints of } \\
\text { Priority } 1,2 \text {, and } 3 .\end{array}$ & $38+24=62$ \\
\hline
\end{tabular}

\section{LEGISLATION ON WEB ACCESSIBILITY}

Strong legislation can surely produce the better web accessibility results and countries those have strict laws or policies on web accessibility with actual execution of law provides the more protection to disable people [5]. Many countries worldwide are continuously working to set up the legislation that all governmental websites should be accessible for all citizens including the people with disability. According to $\mathrm{W} 3 \mathrm{C}$ [9], 19 countries already have done their national legislation on web accessibility, Table 3 shows the web accessibility legislation for some of them.

TABLE. III. LEGISLATION ON DISABILITY

\begin{tabular}{|c|c|}
\hline County & Legislation \\
\hline United Kingdom & $\begin{array}{l}\text { - The disability discrimination act } 1995 \\
\text { - Special educational needs and disability act } \\
2001\end{array}$ \\
\hline $\begin{array}{l}\text { United States of } \\
\text { America }\end{array}$ & - Americans with disabilities act (ADA) \\
\hline Australia & - Disability discrimination act 1992 \\
\hline Canada & - Canadian human rights act of 1977 \\
\hline Germany & $\begin{array}{l}\text { - Act on Equal Opportunities for Disabled } \\
\text { Persons of } 27 \text { April } 2002\end{array}$ \\
\hline Ireland & - The Disability Act, 2005 \\
\hline Israel & $\begin{array}{l}\text { - The Equal Rights for People with Disabilities } \\
\text { Law 5758-1998 }\end{array}$ \\
\hline Italy & $\begin{array}{l}\text { Provisions to support the access to } \\
\text { information technologies for the disabled }\end{array}$ \\
\hline New Zealand & - Human Rights Amendment Act 2001 \\
\hline Portugal & $\begin{array}{l}\text { Resolution of the Council of Ministers } \\
\text { Concerning the Accessibility of Public } \\
\text { Administration Web Sites for Citizens with } \\
\text { Special Needs }\end{array}$ \\
\hline
\end{tabular}

Source: W3C, Policies Relating to Web Accessibility

However, Thailand has updated the Web Content Accessibility Guidelines 2.0 (WCAG 2.0) according to their own country requirements and named it: Thailand Web Content Accessibility Guidelines (Th-WCAG) [10], [11]. Now these guidelines gives the roadmap for web developers to 
design websites focusing the accessibility issues and also decision makers take help to form any policy related to web accessibility. The countries those are struggling to establish their own web accessibility guidelines can modify the web content accessibility guidelines designed by $\mathrm{W} 3 \mathrm{C}$ according to their local context as Thailand has done.

\section{BACKGROUND ON E-SERVICE PROVIDED By SAUdI GOVERNMENT AND SAUDI UNIVERSITIESS.}

\section{A. Internet Users:}

Internet facility becomes available in KSA since 1997 [10] and its users are gradually increasing due the increase in Saudi population, improvement in infrastructure, reduction in Internet usage cost and continues improvement in quality of service. According to the internet live stats, total numbers of internet users in Saudi Arabia was about 4.7 million in year 2000 (2.2\% of total Saudi population) and increased to about 20.8 million in year 2016 (64.7\% of total Saudi population) [12]. These users are mainly divided into following four main categories 1) users using e-government services 2) user using university websites 3) user doing online shopping 4) user using social websites.

\section{B. E-Services:}

E-services or e-government is a process of shifting the manual government services to online by using information and communication technology. This transformation from manual to online is important because it provides easy access for all stakeholders to government e-services, reduce the personal cost, save time, increase service and increase the efficiency [6], [13].

The Kingdom of Saudi Arabia has shown great interest and commitment towards the transformation of manual governmental services to online. A Royal Decree [6] was issued to the Ministry of Communication and Information Technology (MCIT) in 2003 to make plans to provide all government services online through internet to all its stakeholders. In response to the Royal Decree, MCIT, Ministry of Finance (MOF) and Communication and Information Technology Commission (CITC) worked together and prepare a plan for e-government and named it Yesser. Moreover many other e-government projects have been started and implemented e.g. national smart identity card, e-payment through "Sadad", social insurance, portal for e-government, public key infrastructure, e-participation, e-procurement etc. By 2016, [14] around 2974 service are provided by all Saudi government agencies, whereas 2668 services are electronic based and only 306 services are traditional services. Saudi government divided its services in different categories for its beneficiaries; Table 4 shows the total number of services provided by government according to its category until May 2017.

According to the UN e-government survey 2016 [15], KSA belongs to the countries which have high e-government development index (EGDI). Table 5 shows the EGDI ranking of Saudi Arabia and its components: Online Service Index (OSI), Telecommunication Infrastructure Index (TII) and Human Capital Index (HCI).
TABLE. IV. NUMBER OF E-SERVICES PROVIDED BY SAUDI GOVERNMENT AND ITS BENEFICIARIES

\begin{tabular}{|c|c|c|c|c|}
\hline \multirow{2}{*}{$\begin{array}{l}\text { E-Service } \\
\text { Category }\end{array}$} & \multicolumn{4}{|c|}{ Beneficiaries } \\
\hline & Individual & Business & $\begin{array}{l}\text { Public } \\
\text { entities }\end{array}$ & Visitors \\
\hline $\begin{array}{l}\text { Information and } \\
\text { Communication } \\
\text { Technology }\end{array}$ & 16 & 12 & 16 & 0 \\
\hline $\begin{array}{l}\text { Economy and } \\
\text { business }\end{array}$ & 172 & 288 & 149 & 2 \\
\hline $\begin{array}{l}\text { Training, } \\
\text { education, and } \\
\text { culture }\end{array}$ & 412 & 54 & 52 & 2 \\
\hline $\begin{array}{l}\text { Travel and } \\
\text { Tourism }\end{array}$ & 31 & 11 & 6 & 11 \\
\hline Islamic affairs & 57 & 38 & 32 & 5 \\
\hline Labor & 42 & 42 & 18 & 0 \\
\hline $\begin{array}{l}\text { Insurance and } \\
\text { pension }\end{array}$ & 45 & 47 & 12 & 0 \\
\hline Social life & 110 & 6 & 13 & 2 \\
\hline $\begin{array}{l}\text { Housing and } \\
\text { municipality }\end{array}$ & 183 & 127 & 54 & 1 \\
\hline $\begin{array}{l}\text { Health and } \\
\text { environment }\end{array}$ & 99 & 61 & 31 & 2 \\
\hline Utilities & 39 & 33 & 13 & 0 \\
\hline Transportation & 40 & 85 & 16 & 0 \\
\hline $\begin{array}{l}\text { Traffic and } \\
\text { safety }\end{array}$ & 36 & 23 & 18 & 0 \\
\hline $\begin{array}{l}\text { Personal } \\
\text { documentations }\end{array}$ & 123 & 34 & 42 & 1 \\
\hline
\end{tabular}

TABLE. V. E-GOVERNMENT DEVELOPMENT INDEX (EGDI) OF SAUDI ARABIA

\begin{tabular}{|l|l|l|l|l|l|l|}
\hline $\begin{array}{l}\text { EGDI } \\
\text { World } \\
\text { Ranking } \\
\mathbf{2 0 1 6}\end{array}$ & $\begin{array}{l}\text { Asian } \\
\text { Ranking }\end{array}$ & $\begin{array}{l}\text { EGDI } \\
\text { Level }\end{array}$ & $\begin{array}{l}\text { EGDI } \\
\text { Value }\end{array}$ & OSI & HCI & TII \\
\hline 44 & 9 & High & 0.6822 & 0.6739 & 0.5733 & 0.6822 \\
\hline TII and its components per 100 inhabitants & $\begin{array}{l}\text { Mobile- } \\
\text { cellular } \\
\text { telephone } \\
\text { subscriptio } \\
\text { telephone } \\
\text { subscripti } \\
\text { ons }\end{array}$ & $\begin{array}{l}\text { cellular } \\
\text { telephone } \\
\text { subscriptio } \\
\text { ns }\end{array}$ & $\begin{array}{l}\text { Fixed (wired)- } \\
\text { broadband } \\
\text { subscriptions }\end{array}$ & $\begin{array}{l}\text { Wireless } \\
\text { broadband } \\
\text { subscriptions }\end{array}$ \\
\hline 63.70 & 13.36 & 179.56 & 10.36 & 70.60 \\
\hline
\end{tabular}

Source: UN E-Government Survey 2016 


\section{Saudi Universities:}

Saudi Arabian government has shown great commitment and support towards the higher education in past 10 years and continuation in coming years. Moreover most of these institutions have adopted the e-learning and online centric programs.

Saudi Arabia has total 73 colleges and universities, among them about 26 are public sector universities which are fully funded by government [16]. King Saud University is first university which was established in 1957 and University of Jeddah is the newest university established in 2014.

Student's enrolment in both public sector and private sector universities is gradually increasing due to the continues increase in universities during past 10 years. In 2001, total numbers of students in higher education programs were 432,000 and become 1.5 million in 2014. Moreover it is estimated that students' number will reach 2.537 million in 2022 [17].

All colleges and universities have their own website and most of the website are bilingual (English and Arabic). These websites are not only used by current students, it can be accessed by prospective students, alumni students, program advisory committee, student's family members, international user etc. So it is very important that users with disability can also access the website same as the normal user can access because most of the universities are providing the online services to students such as online library, online course registration, current student's surveys and alumni surveys. Elearning was started in 2002 in Saudi Arabia [18] and since it is gradually shifting their traditional teaching system to web based learning in higher education programs. Now most of the universities in kingdom have adopted BlackBoard as Learning Management System (LMS) and smart classroom automation techniques [19]. Both faculty members and students are required to use LMS during their regular class activities e.g. organizing virtual classes, online attendance, uploading assignments, student grades etc. This transformation from traditional teaching style to e-learning demands to improve the web accessiblity of university and college websites. However exiting research studies shows that university website have many web accessibility issues which need to be handle properly.

\section{EXISTING RESEARCH STUdIES ON WEB ACCESSIBILITY}

Literature review reveals that many research studies have been conducted in past two decades on web accessibility around the world and few are done in Saudi Arabia as well. Following five research studies fulfilled the selection criteria which are completed since 2010 to explore the web accessibility issue for disable people in Saudi Arabia.

In 2010, Mukhtar M. Rana, et al., [20] used automatic web accessibility analysis tools JAWS and Supernova to evaluate the web accessibility of home page of 25 Saudi university websites against the web accessibility guidelines provided by World Wide Web consortium. Functional accessibility analysis on university websites shows that, navigation and orientation, text equivalent and styling are partially implemented and average errors are $24.30 \%, 28.15 \%$ and $38.02 \%$ respectively.
Moreover scripting and HTML standards are completely implemented with average errors $0 \%$ in scripting and $8.53 \%$ HTML standards. Study concluded that $80 \%$ university websites in Saudi Arabia are not following the web accessibility guidelines also web developers are not fully aware of the web accessibility guidelines. Another study [21] was conducted to identify the challenges which affect the web accessibility of Saudi Arabian university websites by doing interviews from 15 experts in 9 Saudi universities. Study identified the eight main challenges which need to address to improve the web accessibility. However one of the core challenges was the negative attitude toward addressing the disability issues. Web accessibility in Saudi Arabian university is continues challenge which need to address properly by doing further research to explore the problems faced by disable user and consider user's problem during designing the university websites

Hend S. Al-Khalifa [10] evaluated the accessibility of Arabic version of 36 Saudi government websites to check the conformance level with WCAG 2.0. Each homepage was inspected manually with the help of evaluation tool WAVE toolbar and web developer toolbar. It is noted that each governmental website has violated the web accessibility guidelines and no website is following minimum guidelines of WCAG 2.0. According to the Saudi national portal; currently 2974 services provided by all Saudi government agencies, whereas 2668 services out of 2974 are electronic based which clearly give the indication of importance for improvement of web accessibility in governmental websites.

Addin Osman [22] performed a systematic literature review to evaluate the available automatic web accessibility tools and the web accessibility of website globally and in Saudi Arabia based on the web content accessibility guidelines. Study reveals that it is required to improve the accessibility of websites globally and in Saudi Arabia and web accessibility awareness among web masters and decision makers in Saudi Arabia. Knowledge about web accessibility for decision makers and web developer is also an important factor which can affect the improvement of web accessibility.

Majed Alshamari [23] examined the homepage of three popular online shopping websites in Saudi Arabia using accessibility evaluation tools: AChecker, TAW, MAUVE, EvalAcess and Functional Assessment Evaluation 2.0. Study concluded that selected websites have navigation errors, readability errors, HTML errors, and input assistance and timing errors. Moreover they suggested some recommendation and point out that involvement of web accessibly experts in evaluation can give better results.

Table 6 below present the summary of all reviewed article on web accessibility conducted globally and in Saudi Arabia. Web accessibility is a global issue and especially in developing countries web accessibility situation is not very good as compared to developed countries.

Developing countries including Saudi Arabia needs to put web accessibility as a high priority issue to solve because disable user are not fully get benefited from the eservice provided by government and universities due to poor web accessibility. 
TABLE. VI. SUMARY OF EXISTING RESEARCH STUDIES ON WEB ACCESSIBILITY

\begin{tabular}{|c|c|c|c|}
\hline Author, Year & Objective/Purpose of Study & Research Methodology & Results/Output \\
\hline $\begin{array}{l}\text { Addin Osman } \\
(2017) \\
{[22]} \\
\text { Saudi Arabia }\end{array}$ & $\begin{array}{l}\text { To evaluate the web accessibility of } \\
\text { website globally and in Saudi Arabia } \\
\text { based on the web content accessibility } \\
\text { guidelines. }\end{array}$ & Systematic Literature Review & $\begin{array}{l}\text { Researcher concluded that it is } \\
\text { required to improve the accessibility } \\
\text { of websites globally and in Saudi } \\
\text { Arabia specifically. It is required to } \\
\text { check the web accessibility of } \\
\text { website in Saudi Arabia. }\end{array}$ \\
\hline $\begin{array}{l}\text { Majed Alshamari } \\
(2016) \\
{[23]} \\
\text { Saudi Arabia }\end{array}$ & $\begin{array}{l}\text { To evaluate the supporting tools used by } \\
\text { disable people to access the websites and } \\
\text { accessibility analysis of three popular e- } \\
\text { commerce website using automatic tools. }\end{array}$ & $\begin{array}{l}\text { Five automatic accessibility evaluation tools } \\
\text { AChecker, TAW, Eval Access, MAUVE and } \\
\text { FAE was used to test the accessibility of } \\
\text { selected e-commerce websites. }\end{array}$ & $\begin{array}{l}\text { Result shows that selected websites } \\
\text { have navigation errors, readability } \\
\text { errors, HTML errors, and input } \\
\text { assistance and timing errors. } \\
\text { Moreover involvement of web } \\
\text { accessibly experts in evaluation can } \\
\text { give better results. }\end{array}$ \\
\hline $\begin{array}{l}\text { Asmaa Alayed et. al. } \\
(2016) \\
\text { [21]. } \\
\text { Saudi Arabia }\end{array}$ & $\begin{array}{l}\text { To identify the challenges which affect } \\
\text { the web accessibility of Saudi Arabian } \\
\text { university websites. }\end{array}$ & $\begin{array}{l}\text { Interviews were conducted from } 15 \text { experts in } 9 \\
\text { Saudi universities. }\end{array}$ & $\begin{array}{l}\text { Identified the eight main challenges } \\
\text { which need to address to improve } \\
\text { the web accessibility. }\end{array}$ \\
\hline $\begin{array}{l}\text { Hend S. Al-Khalifa } \\
(2012) \\
{[10]} \\
\text { Saudi Arabia }\end{array}$ & $\begin{array}{l}\text { To evaluate the Saudi Arabian } \\
\text { government websites on the bases of the } \\
\text { guidelines provided by the W3C. }\end{array}$ & $\begin{array}{l}\text { Comprehensive literature review and assess the } \\
\text { home page of Saudi government websites }\end{array}$ & $\begin{array}{l}\text { Found many accessibility errors and } \\
\text { no governmental website is } \\
\text { following minimum guidelines of } \\
\text { WCAG } 2.0\end{array}$ \\
\hline $\begin{array}{l}\text { Mukhtar M. Rana et al. } \\
(2011) \\
\text { [20] } \\
\text { Saudi Arabia }\end{array}$ & $\begin{array}{l}\text { To evaluate the accessibility of } 21 \text { Saudi } \\
\text { university websites using assistive } \\
\text { technologies such as JAWS and } \\
\text { Supernova. }\end{array}$ & $\begin{array}{l}\text { Qualitative approach } \\
\text { Screen readers JAWS and Supernova were } \\
\text { used. }\end{array}$ & $\begin{array}{l}\text { The research revealed that } 80 \% \text { of } \\
\text { universities have low accessibility } \\
\text { standards and could not achieve } \\
\text { minimum ' } A \text { ' conformance }\end{array}$ \\
\hline $\begin{array}{l}\text { Mohd Hanapi et al. } \\
(2010) \\
{[24]} \\
\text { Malaysia }\end{array}$ & $\begin{array}{l}\text { To evaluate the accessibility of nine } \\
\text { Malaysian e-government website on the } \\
\text { bases of guidelines provided by the } \\
\text { World Wide Web Consortium (W3C) } \\
\text { and also to identify that webmasters have } \\
\text { knowledge of W3C guidelines. }\end{array}$ & $\begin{array}{l}\text { - Nine Malaysian government websites was } \\
\text { chosen to evaluate the web accessibility. } \\
\text { - Automatic tool Bobby was used to evaluate } \\
\text { the websites. } \\
\text { - Only the main page of these websites was } \\
\text { tested. } \\
\text { - Interviews conducted with webmasters and } \\
\text { website developers. }\end{array}$ & $\begin{array}{l}\text { No single government website is } \\
\text { following W3C proposed guidelines. } \\
\text { Also most of the webmasters did not } \\
\text { have clear idea of W3C proposed } \\
\text { guidelines. }\end{array}$ \\
\hline $\begin{array}{l}\text { Yakup Akgul et al. } \\
(2016) \\
{[25]} \\
\text { Turkey }\end{array}$ & $\begin{array}{l}\text { Homepage of twenty five Turkish } \\
\text { government websites was evaluated to } \\
\text { check the web accessibility for disable } \\
\text { people }\end{array}$ & $\begin{array}{l}\text { TML and CSS validity was checked by } \\
\text { automatic evaluation tools, Markup } \\
\text { Validation Service and CSS validator service. } \\
\text { - Web accessibility was checked by AChecker, } \\
\text { eXaminator, TAW, Total Validator, WAVE, } \\
\text { Web Accessibility Assessment Tool, Eval } \\
\text { Access, Cynthia Says, MAGENTA, HERA, } \\
\text { Amp and Sort Site }\end{array}$ & $\begin{array}{l}\text { Mostly websites did not meet } \\
\text { minimum level of web accessibility } \\
\text { requirements. Moreover only four } \\
\text { web sites (about } 16 \% \text { ) are using } \\
\text { proper HTML5 DOCTYPE and only } \\
\text { five websites (about 20\%) have } \\
\text { some use of ARIA. }\end{array}$ \\
\hline $\begin{array}{l}\text { Solomon Adelowo } \\
\text { Adepoju } \\
\text { et al. }(2016) \\
\text { [26] } \\
\text { Nigeria }\end{array}$ & $\begin{array}{l}\text { To evaluate the accessibility and } \\
\text { performance of Nigerian e-Government } \\
\text { websites. }\end{array}$ & $\begin{array}{l}\text { Automatic tools: TAW and site analyzer was } \\
\text { used to measure the conformance level of e- } \\
\text { government with WCAG. }\end{array}$ & $\begin{array}{l}\text { None of the Nigerian government } \\
\text { websites are fully following the } \\
\text { accessibility guidelines. }\end{array}$ \\
\hline $\begin{array}{l}\text { Basel Al Mourad et al. } \\
(2013) \\
{[27][28]} \\
\text { Dubai }\end{array}$ & $\begin{array}{l}\text { To evaluate the accessibility of } 21 \text { Dubai } \\
\text { e-Government websites for conformance } \\
\text { level with WCAG } 1.0 \text { by using automatic } \\
\text { tools. }\end{array}$ & $\begin{array}{l}\text { Main page of the } 21 \text { e-Government website was } \\
\text { evaluated by using accessibility evaluation } \\
\text { tool: TAW ( Test de Accesibilidad Web) }\end{array}$ & $\begin{array}{l}\text { Result shows that many e- } \\
\text { Government websites in Dubai did } \\
\text { not meet the minimum accessibly } \\
\text { conformance level. Main issues are } \\
\text { text equivalents are not provided for } \\
\text { non-text elements and no static } \\
\text { equivalent for dynamic elements. }\end{array}$ \\
\hline $\begin{array}{l}\text { Muhammad Bakhsh et } \\
\text { al. } \\
(2012) \\
\text { [29] } \\
\text { Pakistan }\end{array}$ & $\begin{array}{l}\text { To evaluate the web accessibility of } \\
\text { home page of } 45 \text { central government web } \\
\text { portals in Pakistan on the bases of W3C } \\
\text { guidelines. }\end{array}$ & $\begin{array}{l}\text { Automatic web accessibly checking tools: } \\
\text { Functional accessibility evaluator (FAE ) and } \\
\text { total validator were used to measure the } \\
\text { conformance level with WCAG 2.0. }\end{array}$ & $\begin{array}{l}\text { Researcher s found that W3C } \\
\text { guidelines are not fully followed for } \\
\text { the development of central } \\
\text { government web portals. Navigation } \\
\text { is one of an importance factor to } \\
\text { fully explore the contents of any } \\
\text { website for its users including } \\
\text { disable people but result shows that } \\
\text { only } 2.63 \% \text { websites are fully and } \\
97.37 \% \text { are partially implemented. }\end{array}$ \\
\hline
\end{tabular}




\begin{tabular}{|c|c|c|c|}
\hline $\begin{array}{l}\text { Aidi Ahmi et al. } \\
\text { (2016) } \\
\text { [30] } \\
\text { Malaysia }\end{array}$ & $\begin{array}{l}\text { To evaluate the main page of } 25 \\
\text { Malaysian governmental websites for the } \\
\text { WCAG } 2.0 \text { and Section } 508 \text { guidelines }\end{array}$ & $\begin{array}{l}\text { - Twenty five Malaysian government websites } \\
\text { was chosen to evaluate the web accessibility. } \\
\text { - Automatic tool WAVE and AChecker was } \\
\text { used to evaluate the websites. } \\
\text { - Only the main page of these websites was } \\
\text { tested. . }\end{array}$ & $\begin{array}{l}\text { Study reported three different types } \\
\text { of problems } \\
\text { 1) known problems } \\
\text { 2) likely problems } \\
\text { 3) potential problems } \\
\text { Also Most of the ministry websites } \\
\text { are not designed by following the } \\
\text { WCAG } 2.0 \text { and Section } 508\end{array}$ \\
\hline $\begin{array}{l}\text { Humaira Nazar et al. } \\
\text { (2017) } \\
\text { [31] } \\
\text { Pakistan }\end{array}$ & $\begin{array}{l}\text { To evaluate the accessibility of main } \\
\text { page of } 15 \text { banking websites in Pakistan } \\
\text { for compliance with WCAG } 1.0 \text { and } \\
\text { WCAG } 2.0 \text { using automatic accessibility } \\
\text { tools. }\end{array}$ & $\begin{array}{l}\text { - Fifteen Pakistan banking websites was } \\
\text { chosen to test the web accessibility. } \\
\text { - Automatic tools: Markup validation service, } \\
\text { ACheker, Valet and Eval was used } \\
\text { - Only homepage was analyzed. }\end{array}$ & $\begin{array}{l}\text { Four parameters was test during } \\
\text { evaluating the websites and it is } \\
\text { found the no web site is following } \\
\text { WCAG } 1.0 \text { and WCAG } 2.0 \\
\text { properly. }\end{array}$ \\
\hline $\begin{array}{l}\text { Joanne et al. } \\
(2009) \\
{[5]} \\
\text { EU, Africa and Asia }\end{array}$ & $\begin{array}{l}\text { To evaluate the accessibility of } \\
\text { governmental website located in Europe, } \\
\text { Asia and Africa. }\end{array}$ & $\begin{array}{l}\text { Automatic web accessibility tool TAW was } \\
\text { used to evaluate the websites of six federal } \\
\text { governmental agencies in } 12 \text { countries for } \\
\text { compliance with WCAG } 1.0\end{array}$ & $\begin{array}{l}\text { Results shows that web accessibility } \\
\text { is a global issue but countries those } \\
\text { have strong accessibility law have } \\
\text { better web accessibility situation. }\end{array}$ \\
\hline $\begin{array}{l}\text { Abdulmohsen et al. } \\
\text { [32] }\end{array}$ & $\begin{array}{l}\text { To evaluate the e-Government websites } \\
\text { of Saudi Arabia and Oman for } \\
\text { conformance level with Web Content } \\
\text { Accessibility Guidelines. }\end{array}$ & $\begin{array}{l}13 \text { Saudi e-Government websites and } 14 \\
\text { Omani e-Government websites was evaluated } \\
\text { by tools: Multiweb, LYNX and W3C } \\
\text { validator service. }\end{array}$ & $\begin{array}{l}\text { It is concluded that less importance } \\
\text { to provide the services for people } \\
\text { with special need is key factor and } \\
\text { GCC countries need to review } \\
\text { policies make their e-Government } \\
\text { websites more accessible. }\end{array}$ \\
\hline
\end{tabular}

Fig. 1 shows that $87 \%$ of reviewed articles are using automatic web accessibility evaluation tools to evaluate the homepage of websites, $7 \%$ have used the literature review technique and only $6 \%$ completed their studies on the bases of interviews. Fig. 2 shows that 14 automatic web accessibility evaluation tools were used in reviewed articles and TAW is the mostly used tool followed by AChecker and EvalAccess.

Percentage of methodology used by reviewed articles

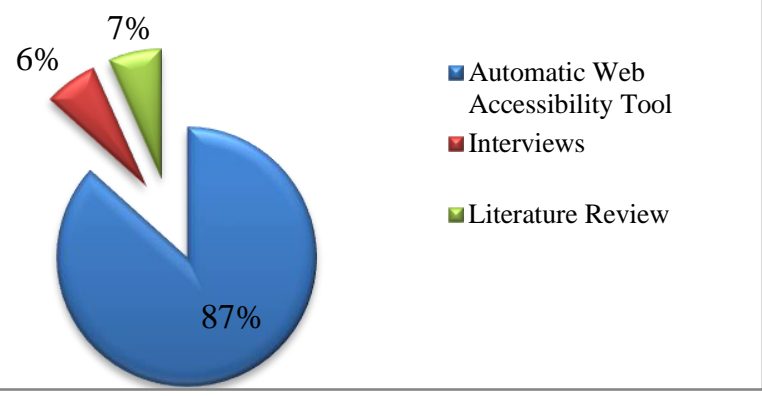

Fig. 1. Percentage of methodology used by authors.

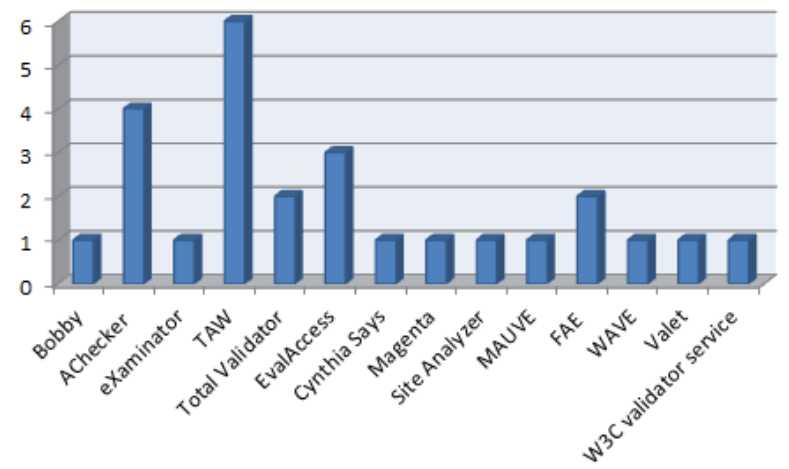

Fig. 2. Usage of automatic web accessibility tools.

\section{RESEARCH METHODOLOGY}

In this paper systematic literature review (SLR) methodology is used for the identification and critically evaluation of exiting literature in the scope of web accessibility.

\section{A. Formation of Research question}

First step in SLR is to form the research questions which need to be address. Three research questions have been defined to determine the web accessibility issue in Saudi Arabia and other countries.

Research question 1: What are the main principles of Web Content Accessibility Guideline 2.0 (WCAG-2.0) proposed by the World Wide Web Consortium (W3C) to improve the web accessibility?

Research question 2: What is the compliance level of university and government websites against WCAG-2.0 globally?

Research question 3: What is the compliance level of Saudi Arabian university and government websites compare to WCAG-2.0?

\section{B. Identification of relevant publications/articles}

Second step in SLR is to identify the relevant studies in the area of web accessibility. So we have following search strategy for the identification of studies.

1) Selection Period: Articles was selected from 2009 to 2017.

2) Keywords used to search the relevant articles: Web accessibility, disability, e-government, web contents accessibility guidelines, WCAG 1.0, WCAG 2.0, accessibility evaluation.

3) Scholarly databases searched: Google scholar, Google search engine, EBSCO host, IEEE Explorer, Science Direct, The Elsevier, Springer Link, ACM digital Library, Wiley and Emerald. 
4) Study Population: Saudi Arabia, UAE, Malaysia, Turkey, Pakistan, Nigeria, UK, France, Germany, Switzerland, China, India, Cambodia, Philpines, South Africa.

5) Outcome: 25 research studies were selected for review.

Identification of relevant research studies in the area of web accessibility is achieved in three layers. Table 7 show the layer model which is divided into basic layer, intermediate layer and advanced layer.

\section{DISCUSSION AND RECOMENDATION}

Analysis of 15 reviewed articles discloses that web accessibility is a global issue and mostly countries including Saudi Arabia is not properly following the guidelines provided by the World Wide Web consortium.

Disable people around the world are not able to fully benefit from services provided by government and universities due to low web accessibility. Web accessibility need to be a key priority for Saudi government because eelectronic service share in Saudi e-government is $89.7 \%$ and mostly Saudi universities have adopted BlackBoard as learning management system (LMS) and smart classroom techniques. Following are the factors which affects the web accessibility of websites:

Literature review explore that many web accessibility issues needs to handle properly in Saudi Arabia and around the world e.g. Navigation errors, orientation issue, timing errors, text equivalent to graphics, content and scripting, validity of HTML and CSS, use of HTML5, interface design, content and scripting.

\section{A. Effect of web accessibility legislation and proper law execution}

Web accessibility legislation is an important factor which needs to address by most of the countries including Saudi Arabia. In [5], reported that countries those have strict web accessibility legislation with proper implementation have improved web accessibility situation for disable peoples. Saudi Arabia [10] signed UN treaty for disable people's rights in June 2008 and makes the legislation by focusing the disability issues but without clearly defined the rules for web accessibility.

\section{B. Lack of web accessibility knowledge}

Web developers and policy makers' awareness of WCAG 1.0 and WCAG 2.0 are very important to improve web accessibility but [21], [24] reported that many web developers are unaware of web accessibility guidelines.
TABLE. VII. LAYERED MODEL FOR IDENTIFICATION OF RELEVANT RESEARCH STUDIES

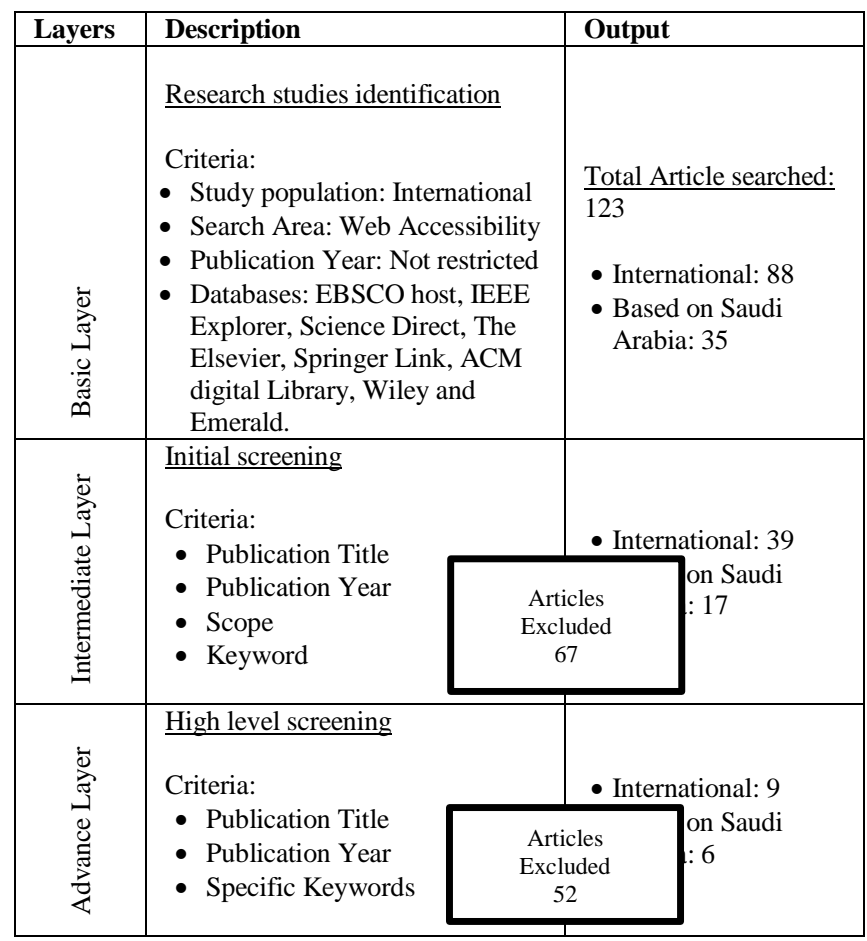

Moreover, André Pimenta [33] made comparisons of problems faced by users with web accessibility guidelines and proved that web accessibility guidelines are not addressing many problems which are faced by user. However disability types vary from country to country, few countries (e.g. UK, Australia, US, Canada) already developed their own accessibility guidelines based on their country's context. Recently, Ontario, one of the provinces of Canada, adapted its own accessibility guidelines based on provincial context to improve the web accessibility for disable peoples [34].

Saudi Arabia also needs to review their policies related to web accessibility and to develop their own web accessibility guidelines according the country context, culture and disability types. This can be achieved by doing in-depth research with following objectives: 1) Evaluate national portals those provide e-governance services and university websites for web accessibility 2) Accumulation of barriers faced by different types of disable people 3) Categorizations of barriers into discrete problems 4) Mapping the discrete problems with WCAG 2.0 guidelines. 


\section{CONCLUSION AND FUTURE WORK}

Web accessibility is one of the main factor to access the quality of any website and if accessibility guidelines are not properly followed then many disable users will not be able to use the services provided by the website. According to the UN e-government survey 2016, Saudi Arabia belongs to the countries those have high level of e-government development index (EGDI). However web accessibility needs to be a top priority issue for Saudi Arabia to address properly so that its $4 \%$ disable citizen can get full benefit from the e-services provided by government.

In this study, a systematic literature review is conducted on selected research studies performed in Saudi Arabia and outside of Saudi Arabia to explore the web accessibility issue in the governmental and university websites. It is found that no website is following the World Wide Web consortium's web accessibility guidelines. Legislation in this regard can play a vital role to improve the web accessibility. It is also noted that some countries have legislation but still facing web accessibility issue due to not proper implementation of web accessibility law.

This paper provides a strong foundation for future work to evaluate the national Saudi portals those provide e-governance services and university websites for web accessibility issues by involving the disable users, web developer, web designer and policy makers. To accumulate the barriers faced by different types of disable people. Then categorize the barriers into discrete problems and to map the discrete problems with WCAG 2.0 guidelines to explore which problem are covered by WCAG 2.0 and which user problems are missing. To address the missing problems will be helpful to do the legislation for web accessibility and to improve the existing web accessibility guidelines according to the local Saudi context.

\section{REFERENCES}

[1] World Health Organization and World Bank, "World Report on Disability", 2011, available at, www.who.int disabilities world report 2011 report.pdf .

[2] United Nations Development Group, Inter-Agency Support Group for the CRPD Task Team, "Including the rights of persons with disabilities in United Nations programming at country level", July 2010, available at, www.undg.org/docs/11534/Disability---G - Annexes.pdf .

[3] KSA has 720,000 disabled, Published by ArabNews, December 2012, available online at http://www.arabnews.com/ksa-has-720000-disabled.

[4] United Nations Treaty Collection, available at.

[5] https://treaties.un.org/Pages/ViewDetails.aspx?src=TREATY\&mtdsg n $\mathrm{o}=\mathrm{IV}-15 \&$ chapter $=4 \&$ clang $=$ en

[6] Kuzma, Joanne and Yen, Dorothy and Oestreicher, Klaus (2009) Global e-government Web Accessibility: An Empirical Examination of EU, Asian and African Sites. In: Second International Conference on Information and Communication Technologies and Accessibility, 7th to 9th May 2009, Hammamet, Tunisia.

[7] R. Kurdi, E. Nyakwende and D. Al-Jumeily, "E-Government Implementation and Readiness: A Comparative Study between Saudi Arabia and Republic of Korea," 2015 International Conference on Developments of E-Systems Engineering (DeSE), Duai, 2015, pp. 279284. doi: 10.1109/DeSE.2015.30.

[8] Web Accessibility Initiative (WAI), available at, http://www.w3.org/wai .

[9] http://www.w3.org/WAI/WCAG20/ .

[10] Policies Relating to Web Accessibility, available at
[11] https://www.w3.org/WAI/Policy/ [Accessed April 22, 2017].

[12] Al-Khalifa, H.S. (2012) The Accessibility of Saudi Arabia Government Web Sites: An Exploratory Study. Universal Access in the Information Society, 11, 201-210. http://dx.doi.org/10.1007/s10209-010-0215-7.

[13] Mitsamarn, Namnueng, Waragorn Gestubtim, and Sirilak Junnatas. "Web accessibility: a government's effort to promote e-accessibility in Thailand." Proceedings of the 1st international convention on Rehabilitation engineering \& assistive technology: in conjunction with 1st Tan Tock Seng Hospital Neurorehabilitation Meeting. ACM, 2007.

[14] Saudi Arabia Internet Users, Internet Live Stats, http://www.internetlivestats.com/internet-users/saudi-arabia/ [Accessed March 13, 2017].

[15] Alshehri M. \& Drew S. "Challenges of e-Government Services Adoption in Saudi Arabia from an e-Ready Citizen Perspective", World Academy of Science, Engineering and Technology, 2010, 66: 1053-1059].

[16] Government Service, avialable at, https://www.saudi.gov.sa/wps/portal/ [Accessed May 12, 2017].

[17] UN E-Government Survey 2016, available at, http://workspace.unpan.org/sites/Internet/Documents/UNPAN96407.pdf [Accessed April 20, 2017].

[18] List of Universities and colleges in Saudi Arabia, https://en.wikipedia.org/wiki/List_of_universities_and_colleges_in_Sau di Arabia .

[19] Nader Habibi, Is Saudi Arabia training too many graduates, University World News: The global window on higher education, Issue No: 376. July $17, \quad 2015$. http://www.universityworldnews.com/article.php?story=2015071401342 2488 [Accessed: April 04, 2017].

[20] Al-Asmari AM, Rabb Khan MS. E-learning in Saudi Arabia: Past, present and future, Near and Middle Eastern Journal of Research in Education 2014:2 http://dx.doi.org/10.5339/nmejre.2014.2

[21] Afifa Jabeen Quaraishi, More Saudi universities boarding e-learning bandwagon, arab news. News published May 10, 2012. http://www.arabnews.com/more-saudi-universities-boarding-e-learningbandwagon.

[22] Masood Rana, Mukhtar; Fakrudeen, Mohammed; Rana, Uzma; "Evaluating Web Accessibility of University Web Sites in the Kingdom of Saudi Arabia." International Journal of Technology, Knowledge \& Society. 2011, Vol. 7 Issue 3, p1-15. 15p.

[23] Asmaa Alayed, Mike Wald and Ea Draffan, Challenges to Enhancing Web Accessibility in Saudi University Websites: An exploratory Study, WEB 2016, The Fourth International Conference on Building and Exploring Web Based Environments, June 2016, Lisbon, Portugal, pages 6-9.

[24] Addin Osman, Web-Accessibility Automatic Checking Tools and Evaluation in Saudi Arabia: A Systematic Literatrue Review, International Journal of Engineering Science and Innovative Technology (IJESIT), Volume 6, Issue 1, January 2017, pp 14 - 17.

[25] Alshamari, M. (2016) Accessibility Evaluation of Arabic E-Commerce Web Sites Using Automated Tools. Journal of Software Engineering and Applications , 9, 439-451. http://dx.doi.org/10.4236/jsea.2016.99029

[26] Mohd Hanapi Abdul Latif and Mohamad Noorman Masrek, Accessibility Evaluation on Malaysian E-Government Websites, Journal of e-Government Studies and Best Practices, Vol. 2010 (2010).

[27] Yakup AKGÜL and Kemal VATANSEVER, "Web Accessibility Evaluation of Government Websites for People with Disabilities in Turkey," Journal of Advanced Management Science, Vol. 4, No. 3, pp. 201-210, May 2016. doi: 10.12720/joams.4.3.201-210.

[28] Solomon Adelowo Adepoju, Ibrahim Shehi Shehu, and Peter Bake, "Accessibility Evaluation and Performance Analysis of e-Government Websites in Nigeria," Vol. 7, No. 1, pp. 49-53, February, 2016. doi: 10.12720/jait.7.1.49-53

[29] Basel Al Mourad and Faouzi Kamoun (2013), " Accessibility Evaluation of Dubai e-Government Websites: Findings and Implications" Journal of E-Government Studies and Best Practices, Vol. 2013 (2013), Article ID 978647, DOI: 10.5171/2013. 978647,

[30] http://creativecommons.org/licenses/by/3.0/. 
[31] Faouzi Kamoun, Mohamed Basel Almourad, (2014) "Accessibility as an integral factor in e-government web site evaluation: The case of Dubai e-government", Information Technology \& People, Vol. 27 Issue: 2, pp.208-228, doi: 10.1108/ITP-07-2013-0130

[32] M. Bakhsh and A. Mehmood, "Web Accessibility for Disabled: A Case Study of Government Websites in Pakistan," 2012 10th International Conference on Frontiers of Information Technology, Islamabad, 2012, pp. 342-347. doi: 10.1109/FIT.2012.68

[33] Aidi Ahmi and Rosli Mohamad, Evaluating Accessibility of Malaysian Ministries Websites using WCAG 2.0 and Section 508 Guidelines, Journal of Telecommunication electronic and computer engineering, Volume 8, No. 8, pp 177-183, 2016.
[34] Humaira Nazar, M. Shahzad Sarfraz and Umar Shoaib, Web Accessibility Evaluation of Banking Website in Pakistan, International Journal of Computer Science and Information Security (IJCSIS), Volume 15, No. 1, pp 642-650, January 2017.

[35] Abanumy A, Al-Badi A, and Mayhew P "e-Government Website Accessibility: InDepth Evaluation of Saudi Arabia and Oman" The Electronic Journal of e-Government Volume 3 Issue 3 pp 99-106.

[36] André Pimenta Freire, "Disabled people and the Web: User-based measurement of accessibility", PhD thesis, University of York, September 2012.

[37] Accessibility laws, Ontario Canada, December 2015, available at https://www.ontario.ca/page/accessibility-laws 